\title{
Biological characterization of purified native 20-kDa human growth hormone
}

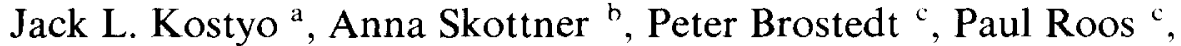 \\ Christopher M. Cameron ${ }^{\mathrm{a}}$, Anders Forsman ${ }^{\mathrm{b}}$, Linda Fryklund ${ }^{\mathrm{b}}$, \\ Naa A. Adamafio ${ }^{a}$ and Bo Skoog ${ }^{b}$ \\ a Department of Physiology, The University of Michigan Medical School, Ann Arbor, MI (U.S.A.), " KabiVitrum AB, \\ Stockholm and 'Department of Biochemistry, University of Uppsala, Uppsala (Sweden)
}

(Received 20 January 1987)

Key words: Growth hormone; Growth-promoting activity; Diabetogenic activity; Insulin-like activity; IGF-1 level; (ob/ob mouse)

Because of the propensity of the 20-kDa variant of human growth hormone (GH) to aggregate with itself and with 22-kDa human GH, it has been difficult to prepare monomeric 20-kDa GH in highly purified form. This has been a major complicating factor in determining whether 20-kDa GH has a biological activity profile distinct from that of $22-\mathrm{kDa}$ GH. In the present study, native $20-\mathrm{kDa}$ GH was isolated from a human GH dimer concentrate and purified by a procedure that included column electrophoresis in agarose suspension as a final separation step. This procedure yielded highly purified monomeric 20-kDa GH, which was contaminated to an extent of less than $1 \%$ with $22-\mathrm{kDa} \mathrm{GH}$, and which exhibited only a small degree of dimerization upon storage. The native $20-\mathrm{kDa}$ GH was quite active in stimulating growth in hypophysectomized rats, when growth was assessed by body weight gain, longitudinal bone growth, the stimulation of sulfation of cartilage, and the elevation of serum IGF-1 level. However, in all of these growth assays, the 20-kDa GH was somewhat less active than the native 22-kDa GH to which it was compared; e.g., in the body weight gain and longitudinal bone growth assays, it had an estimated potency of 0.6 relative to the 22-kDa GH. The 20-kDa GH exhibited substantial diabetogenic activity when tested for the ability to raise fasting blood glucose concentration and to impair glucose tolerance in $o b / o b$ mice. Also, the native 20-kDa GH had significant in vitro insulin-like activity, although its potency was approximately $20 \%$ that of the native 22-kDa GH to which it was compared. Thus, the biological activity profile of native 20-kDa GH differs from that of $22-\mathrm{kDa}$ GH primarily in that insulin-like activity is markedly attenuated.

\section{Introduction}

A variety of structurally modified forms of growth hormone (GH) have been isolated from the human pituitary gland. The predominant

Abbreviation: $\mathrm{GH}$, growth hormone.

Correspondence: J.L. Kostyo, Department of Physiology, The University of Michigan Medical School, Ann Arbor, MI 48109, U.S.A. monomeric form of the hormone present in the gland consists of a single peptide chain of 191 amino acid residues, having a molecular size of approx. $22 \mathrm{kDa}$. About $10 \%$ of the total $\mathrm{GH}$ in the human pituitary is a $20-\mathrm{kDa}$ variant lacking residues $32-46$ of the amino acid sequence [1-5]. This variant occurs because the nucleotides encoding sequence $32-46$ are occasionally deleted during the conversion of $\mathrm{GH}$ pre-mRNA to $\mathrm{GH}$ mRNA [6]. Because of its propensity to aggregate with itself and with $22-\mathrm{kDa} G H, 20-\mathrm{kDa} \mathrm{GH}$ 
exists in human pituitary extracts primarily in various dimeric forms $[2,5]$. As a consequence, it has been quite difficult to prepare monomeric $20-\mathrm{kDa} \mathrm{GH}$ in highly purified form. This has been a major complicating factor in determining whether 20-kDa GH has a biological activity profile distinct from that of $22-\mathrm{kDa} \mathrm{GH}$.

It has been reported previously $[2,7]$ that native $20-\mathrm{kDa} \mathrm{GH}$ is equipotent with $22-\mathrm{kDa} \mathrm{GH}$ in stimulating growth in the hypophysectomized rat, and that it has lactogenic activity in the pigeon crop sac assay equivalent to that of $22-\mathrm{kDa} \mathrm{GH}$ [2]. However, it has been claimed [7,8] that native $20-\mathrm{kDa}$ GH lacks significant diabetogenic and insulin-like activities, which are intrinsic properties of $22-\mathrm{kDa} \mathrm{GH}$. This conclusion was based on the findings that a native $20-\mathrm{kDa}$ GH preparation (a) failed to cause hyperglycemia and glucose intolerance in the dog when given $10 \mathrm{~h}$ prior to a glucose tolerance test [7], (b) did not produce hypoglycemia or decrease plasma free fatty acids when administered acutely to hypophysectomized rats [8], and (c) failed to increase glucose oxidation by isolated rat adipose tissue [8]. This conclusion has been challenged in recent reports demonstrating that bacterially derived biosynthetic human 20-kDa methionyl-GH had both diabetogenic [9] and insulin-like activities $[9,10]$, although the latter was approximately $20 \%$ that of biosynthetic human 22-kDa methionyl-GH [9].

The present study describes the biological characterization of a native $20-\mathrm{kDa} \mathrm{GH}$ preparation that was isolated by a procedure similar to that used by Singh and Lewis [4], but which included a final electrophoretic step. This procedure yielded a highly purified preparation of native $20-\mathrm{kDa} \mathrm{GH}$ having less than $1 \%$ contamination with $22-\mathrm{kDa}$ GH.

\section{Materials and Methods}

\section{Preparation of 20-kDa GH}

The starting material for the isolation of $20-\mathrm{kDa}$ $\mathrm{GH}$ monomer was a human $\mathrm{GH}$ dimer concentrate obtained as a side fraction during the preparation of $22-\mathrm{kDa}$ GH $\left(\right.$ Crescormon $^{\mathbb{B}}$ ) at KabiVitrum AB, according to the method of Roos et al. [11]. About $2.5 \mathrm{~g}$ of dimer concentrate in a volume of 21 , which had been prepared from 4000 human pituitary glands, were utilized. As a first step, the concentrate was dialyzed against $0.005 \mathrm{M}$ potassium phosphate buffer $(\mathrm{pH} 7.0)$ and then applied to a $5 \times 22 \mathrm{~cm}$ column of SP-Sephadex C-50 (Pharmacia, Uppsala, Sweden) to remove human thyrotropic hormone. The column was run at a flow rate of $40 \mathrm{ml} / \mathrm{h}$, and $17-\mathrm{ml}$ fractions were collected. The column was eluted by increasing buffer concentration stepwise, while maintaining constant $\mathrm{pH}$. The thyrotropic hormone was adsorbed on the SP-Sephadex and was later recovered from the column by elution with $0.06 \mathrm{M}$ potassium phosphate buffer [12]. The GH dimer material passed through the column unretarded and was transferred directly to a second column $(2 \times 56 \mathrm{~cm})$ packed with DEAE-Sepharose CL-6B (Pharmacia), which was coupled to the SP-Sephadex column by plastic tubing. The DEAE-Sepharose column had been equilibrated with $0.005 \mathrm{M}$

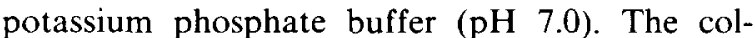
umns were then disconnected, and the dimer material was eluted from the DEAE-Sepharose column with $0.5 \mathrm{M}$ potassium phosphate buffer ( $\mathrm{pH} 7.0$ ). This step concentrated the dimer fraction 25-fold, making it possible to proceed to molecular sieve chromatography directly.

The concentrated dimer fraction was divided into two equal portions of $29 \mathrm{ml}(700 \mathrm{mg})$, and each was applied to a separate $3.2 \times 150 \mathrm{~cm}$ column of Sephadex G-100 (Pharmacia) that had been equilibrated with $0.05 \mathrm{M}$ ammonium bicarbonate. The columns were then eluted with this same solution at a flow rate of $25 \mathrm{ml} / \mathrm{h}$, and $10-\mathrm{ml}$ fractions were collected. Most of the material applied appeared as dimer. About $8 \%$ was highmolecular-mass material, and $16 \%$ was $22-\mathrm{kDa}$ GH. No $20-\mathrm{kDa}$ GH was detectable in the descending part of the monomer $22-\mathrm{kDa}$ GH peak, as reported earlier by Singh and Lewis [4]. The fractions containing the $\mathrm{GH}$ dimer material were pooled and lyophilized. The heterogeneity of this dimer material is apparent in its SDS-polyacrylamide gel electrophoresis pattern (Fig. 1, lane 2) and its analytical isoelectric focusing pattern (Fig. 2, lane 2)

The lyophilized dimer material was then submitted to ion-exchange chromatography in the presence of urea, which splits noncovalent dimers to monomers and increases the charge differences 


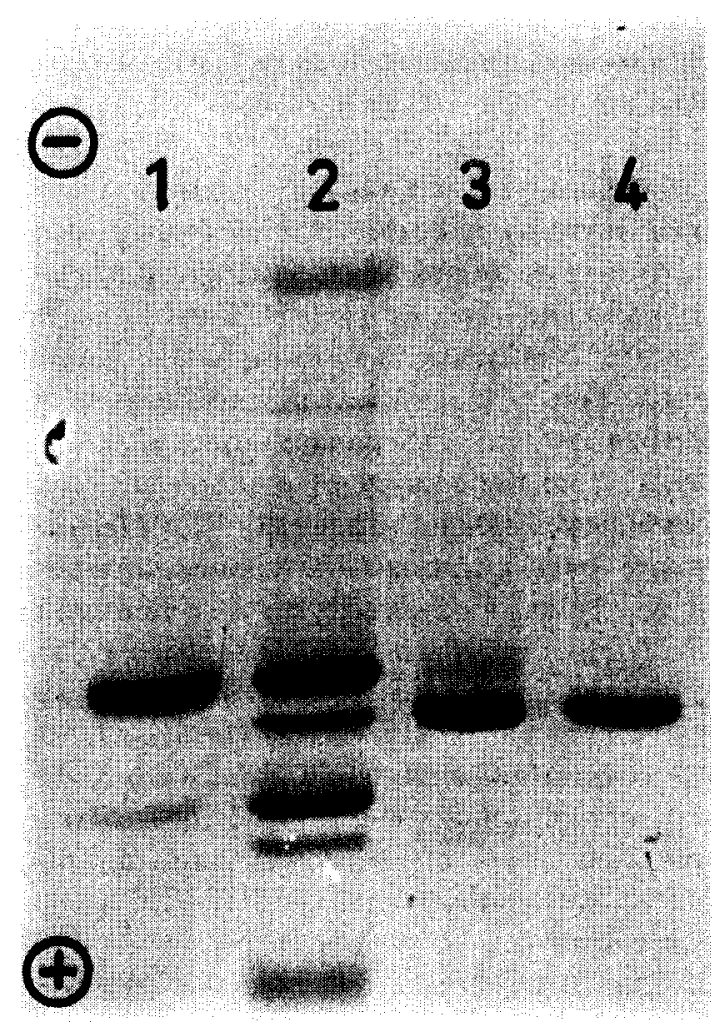

Fig. 1. Analytical SDS-polyacrylamide gel electrophoresis of (1) 22-kDa GH, (2) GH dimer from Sephadex G-100 chromatography, (3) pooled material (peak 3) from chromatography on DEAE-Sepharose CL-6B in $6 \mathrm{M}$ urea, and (4) the final $20-\mathrm{kDa}$ GH pool from zone electrophoresis in agarose suspension.

between $20-\mathrm{kDa} \mathrm{GH}$ and $22-\mathrm{kDa} \mathrm{GH}$. The material was dissolved in $6 \mathrm{M}$ urea (analytical grade, Merck, Darmstadt, F.R.G.), and the conductivity of the solution was adjusted to $1.1 \mathrm{mmho}$ with solid ammonium bicarbonate. The sample (700 mg) was then applied to a $2 \times 23 \mathrm{~cm}$ column packed with DEAE-Sepharose CL-6B that had been equilibrated with $6 \mathrm{M}$ urea-ammonium bicarbonate buffer ( $1.1 \mathrm{mmho})$. All urea-ammonium bicarbonate solutions used in this procedure were passed through $0.2-\mu \mathrm{m}$ filters and were used immediately. The column was washed with the above urea-ammonium bicarbonate buffer, and then the material bound to the column was eluted by increasing the conductivity of the elution buffer in a steep, stepwise fashion (from 1.1 to $5.0 \mathrm{mmho}$ ) by the addition of solid ammonium bicarbonate. The

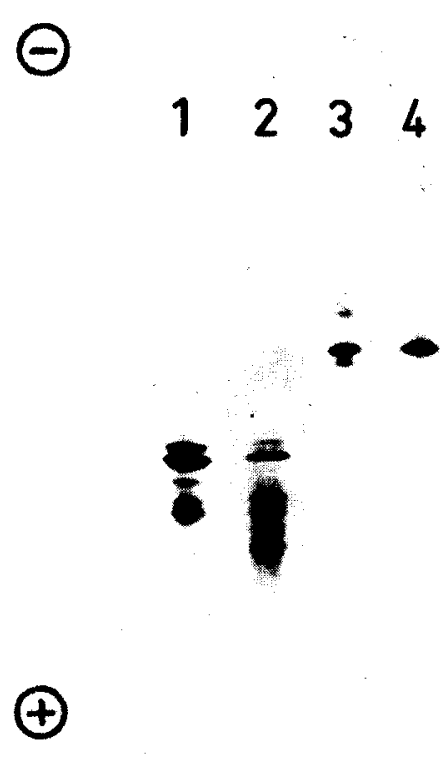

Fig. 2. Analytical isoelectric focusing in agarose gel $(\mathrm{pH}$ 4.0-6.5) of (1) $22-\mathrm{kDa} \mathrm{GH}$, (2) GH dimer from Sephadex G-100 chromatography, (3) pooled material (peak 3) from chromatography on DEAE-Sepharose CL-6B in $6 \mathrm{M}$ urea, and (4) the final $20-\mathrm{kDa} \mathrm{GH}$ pool from zone electrophoresis in agarose suspension.

elution pattern obtained is shown in Fig. 3. Four relatively sharp peaks were obtained. Peak 1 was contaminated with high-molecular mass materials. Peaks 2 and 3 were both primarily 20-kDa GH, and peak 4 was $22-\mathrm{kDa} \mathrm{GH}$. When the conductivity of the elution buffer was subsequently raised to $10 \mathrm{mmho}$, covalent dimeric $\mathrm{GH}$ was eluted from the column. The recovery of $20-\mathrm{kDa} \mathrm{GH}$ in peaks 2 and 3 amounted to a total of $48 \mathrm{mg}$. Analysis of individual fractions in those peaks by SDS-polyacrylamide gel electrophoresis indicated contamination with $22-\mathrm{kDa} \mathrm{GH}$ in the range of $3-10 \%$, depending upon the particular fraction examined (see Fig. 1, lane 3). The SDS-polyacrylamide gel electrophoresis patterns of fractions from peak 2 and peak 3 were similar. Whether peak 2 contains an isoform of $20-\mathrm{kDa} \mathrm{GH}$ or represents overlapping material from peak 3 remains to be answered. It should be noted here that in the previous work of Singh and Lewis [4] a less steep increase in the conductivity of the elution buffer was used, which resulted in a long trailing 


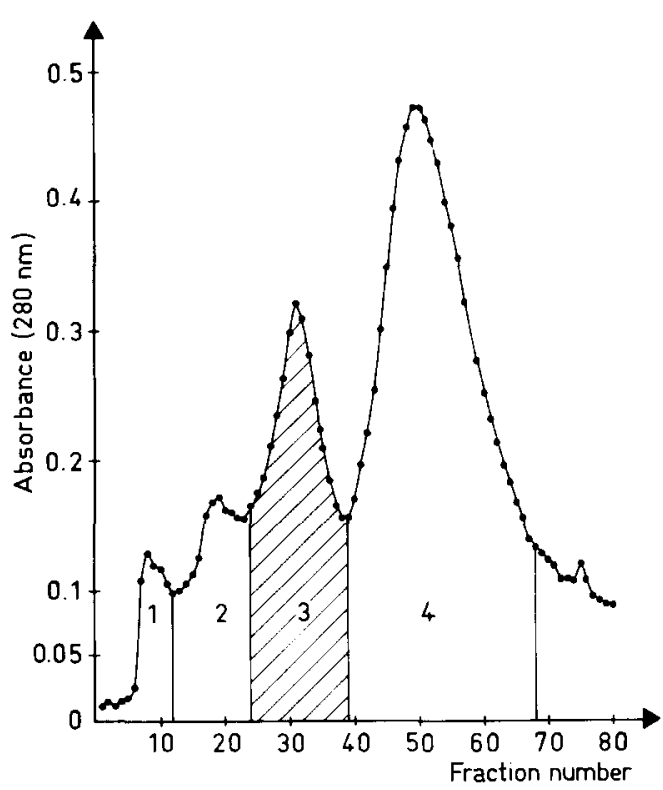

Fig. 3. Chromatography on DEAE-Sepharose CL-6B of GH dimer from molecular sieve chromatography. The buffer was 6 $\mathrm{M}$ urea adjusted to a conductivity of $5.0 \mathrm{mmho}$ with solid ammonium bicarbonate. Flow rate was $40 \mathrm{ml} / \mathrm{h}$, and fraction size was $10 \mathrm{ml}$. The hatched area (peak 3) represents the $20-\mathrm{kDa} \mathrm{GH}$-containing fractions that were utilized for further purification.

peak, having less than $5 \%$ contamination with 22-kDa GH, as judged by SDS-polyacrylamide gel electrophoresis.

In a final separation step, the pooled and ultrafiltered fractions corresponding to peak 3 in the DEAE-Sepharose chromatogram (Fig. 3) were subjected to column electrophoresis in agarose suspension according to the method of Hjertén [13]. The 22-kDa GH contamination of this pool was about $7 \%$. The electrophoresis was performed in $0.15 \mathrm{M}$ glycine-sodium hydroxide buffer $(\mathrm{pH}$ 8.8) which also contained $6 \mathrm{M}$ urea. Because of the presence of urea, the content of agarose (Agarose C, Pharmacia) had to be increased to $0.30 \%(\mathrm{w} / \mathrm{v})$, which is approximately twice that normally used. The solid urea was added to the boiled agarose suspension after it had cooled to $50^{\circ} \mathrm{C}$. The agarose suspension was then left overnight to cool and stabilize. The gel which formed was broken by gentle stirring and poured into the electrophoresis tube $(1.0 \times 65 \mathrm{~cm})$. The concentrated sample (11 $\mathrm{mg}$ in $0.7 \mathrm{ml}$ ), which was stabilized by being mixed with the pellet from a $1.05-\mathrm{ml}$ aliquot of the agarose suspension that had been centrifuged, was applied close to the cathode. Electrophoresis was carried out for $30000 \mathrm{~V} \cdot \mathrm{h}$. The column was then emptied from the top by sucking out fractions of approx. $0.8 \mathrm{ml}$ each with a thin plastic tube. The distribution of protein among the fractions was determined by measuring the difference in their absorbance at 280 and 310 $\mathrm{nm}$ [14]. The agarose was removed from the fractions by centrifugation at $40000 \times g$ for $1 \mathrm{~h}$ at $4^{\circ} \mathrm{C}$. The $20-\mathrm{kDa}$ GH-containing fractions, as determined by SDS-polyacrylamide gel electrophoresis, were then pooled. SDS-polyacrylamide gel electrophoresis of this $20-\mathrm{kDa} \mathrm{GH}$ pool prior to lyophilization is shown in Fig. 1 (lane 4). It is clear that the zone gel electrophoresis step gave a very effective separation of $20-\mathrm{kDa}$ GH from $22-$ $\mathrm{kDa} \mathrm{GH}$. When this material was submitted to polyacrylamide gel electrophoresis in the absence of SDS or 2-mercaptoethanol, the $20-\mathrm{kDa} \mathrm{GH}$ migrated as monomer, indicating a complete and lasting conversion of the substance to monomeric form.

The $20-\mathrm{kDa} \mathrm{GH}$ pool was dialyzed against $0.005 \mathrm{M}$ ammonium bicarbonate and lyophilized. To eliminate salt completely, the lyophilized material was suspended in $0.001 \mathrm{M}$ ammonium bicarbonate and relyophilized. Analysis of the lyophilized $20-\mathrm{kDa}$ GH preparation indicated that it was contaminated to an extent of less than $1 \%$ with $22-\mathrm{kDa} \mathrm{GH}$. Supporting evidence for the homogeneity of this $20-\mathrm{kDa} \mathrm{GH}$ preparation was obtained by submitting it to analytical isoelectric focusing (see Fig. 2, lane 4). The lyophilized preparation was submitted to polyacrylamide gel electrophoresis in the absence of SDS and 2mercaptoethanol after storage for 2 months at $4^{\circ} \mathrm{C}$ in the dry form and subsequently for 6 months at $-20^{\circ} \mathrm{C}$ as a frozen solution $(1 \mathrm{mg} / \mathrm{ml}$ in $0.001 \mathrm{M}$ ammonium bicarbonate). Scanning the stained gels at $560 \mathrm{~nm}$ revealed the presence of only about $15 \%$ dimeric material. This suggests that this preparation of $20-\mathrm{kDa}$ GH is more stable upon storage than that made earlier [4] by somewhat different methods.

Polyacrylamide gel electrophoresis in the presence or absence of SDS and 2-mercaptoethanol was carried out according to the methods of $\mathrm{Ne}$ - 
ville [15]. The composition of the gel was $\mathrm{T}=18.5 \%$ and $\mathrm{C}=1 \%$ (the notation of Hjertén [16]), and the buffers used were chosen to obtain a pH of 10.50 . The gels were stained with Coomassie brilliant blue in a solution of $50 \%$ methanol $/ 7 \%$ acetic acid and destained in a solution of $10 \%$ methanol/7\% acetic acid. Isoelectric focusing in agarose gel was performed with equipment manufactured by Pharmacia according to methods provided by the supplier. Pharmalyte ${ }^{\circledR 5}$ ( $\mathrm{pH} 4.0-6.5$ ) was used, and approx. 2- $\mu$ g samples were applied. After termination of isoelectric focusing, the proteins were visualized by silver staining [17].

Protein concentration was estimated throughout by measuring absorbance at $280 \mathrm{~nm}$ in a $1 \mathrm{~cm}$ cell. 1 unit of absorbance was assumed to correspond to a protein concentration of $1 \mathrm{mg} / \mathrm{ml}$.

The purification procedure was guided in part by radioimmunoassays performed with a double antibody technique.

\section{Assays for growth-promoting activity}

Two comprehensive growth studies (experiments 1 and 2) were conducted in the following manner. Hypophysectomized male rats $(80-100 \mathrm{~g}$ body weight) of the Sprague-Dawley strain were purchased from Mollegaard Breeding Labs, Denmark, and were used for experiments 2 weeks after the operation. On the first day of the experiment, each animal received an intraperitoneal injection of $0.8 \mathrm{mg}$ of tetracycline (Terramycin ${ }^{\otimes}$, Pfizer) in $0.5 \mathrm{ml}$ saline for the subsequent measurement of longitudinal bone growth [18-20]. They were also given a subcutaneous injection of $40 \mu \mathrm{g}$ cortisone acetate (Upjohn) in $0.5 \mathrm{ml}$ saline. On this day, each animal was also lightly anesthetized with diethyl ether, and a blood sample was taken from the retroorbital plexus to obtain serum, which was frozen for subsequent analysis of IGF-1 level. On days 2 and 3 , the injections of cortisone acetate were repeated. On days 4 and 5 , each rat received an intraperitoneal injection of $10 \mu \mathrm{g}$ of L-thyroxine (Sigma) in $0.5 \mathrm{ml}$ saline that had been made alkaline with $\mathrm{NaOH}$. On days $6-15$ of the experiment, the animals received two daily subcutaneous injections (morning and late afternoon) of $0.5 \mathrm{ml}$ of either vehicle, native $22-\mathrm{kDa} \mathrm{GH}$ or native $20-\mathrm{kDa}$ GH (6 or $60 \mu \mathrm{g} /$ day). On day 6 , each animal was again anesthetized with diethyl ether, and another blood sample was taken for the measurement of IGF-1 [21]. On day 15, all animals received an intraperitoneal injection of $\left[{ }^{35} \mathrm{~S}\right]$ sulfate for the measurement of sulfate incorporation into cartilage, as described previously by Skottner et al. [22]. On the following day, a final blood sample was obtained for the measurement of IGF-1 level, and the animals were then decapitated, and various tissues were removed for analysis.

The native $22-\mathrm{kDa}$ GH used in the growth-promoting assays was Crescormon ${ }^{\otimes}$ (KabiVitrum AB) (3 IU $/ \mathrm{mg}$ ), which had been desalted on PD-10 columns (Pharmacia) that were equilibrated with $0.1 \mathrm{M}$ ammonium bicarbonate. The protein concentration of the desalted hormone solution was estimated by measuring its absorbance at $280 \mathrm{~nm}$, assuming an absorption coefficient $\left(A_{280}, 0.1 \%\right.$ $(\mathrm{w} / \mathrm{v})$ solution, $1 \mathrm{~cm}$ ) for $22-\mathrm{kDa} \mathrm{GH}$ of 0.76 . (This absorption coefficient for $22-\mathrm{kDa}$ GH was empirically determined. Corrected ultraviolet spectra of desalted sample solutions were compared to their protein contents estimated from the amino acid composition of lyophilized, hydrolysed samples.) The hormone solution was then diluted with saline, and aliquots of the diluted solution were frozen. Fresh aliquots of frozen hormone were thawed and used immediately for each injection. The $20-\mathrm{kDa}$ GH used for the growth-promoting assays was an aliquot of the final $20-\mathrm{kDa} \mathrm{GH}$ pool. For the first growth study (experiment 1), a sample of the final $20-\mathrm{kDa} \mathrm{GH}$ pool was frozen and maintained at $-70^{\circ} \mathrm{C}$ until it was diluted for use in experiments. The protein concentration of this solution was estimated by measuring its absorbance at $280 \mathrm{~nm}$, assuming an absorption coefficient of 0.70 (as determined for $22-\mathrm{kDa} G H$ ). The somewhat lower absorption coefficient is consistent with the loss of two tyrosine residues in the deletion peptide $32-46$, and is in accord with the previous observation of Chapman et al. [5] showing about a $10 \%$ difference in the absorption coefficients of $22-\mathrm{kDa} \mathrm{GH}$ and $20-\mathrm{kDa} \mathrm{GH}$. The $20-\mathrm{kDa} \mathrm{GH}$ solution was diluted with saline, and aliquots were frozen. Fresh aliquots of frozen $20-$ kDa GH were thawed and used immediately for each injection. For experiment 2, a sample of the final $20-\mathrm{kDa}$ GH pool was divided into aliquots, and these were then lyophilized individually. Each morning, a lyophilized aliquot of the $20-\mathrm{kDa} \mathrm{GH}$ 
was dissolved in saline and used for injections immediately. The remainder of the aliquot was refrozen and stored at $-70^{\circ} \mathrm{C}$ until the afternoon, when it was thawed and used for the second series of injections.

The potency of the $20-\mathrm{kDa} \mathrm{GH}$ relative to that of $22-\mathrm{kDa} \mathrm{GH}$ in stimulating weight gain and longitudinal bone growth was estimated using a parallel line bioassay program [23].

\section{Assay for diabetogenic activity}

The diabetogenic activity of the native $20-\mathrm{kDa}$ $\mathrm{GH}$ was assessed in female $o b / o b$ mice as previously described in detail $[24,25]$. The final relyophilized preparation of the $20-\mathrm{kDa} \mathrm{GH}$ was used for these experiments (see above), and the doses of hormone given were based on actual weight of the dried hormone. A fresh solution of the hormone was used each day for the injections. The hormone was dissolved in distilled water made slightly alkaline with $\mathrm{NaOH}$ and administered in a volume of $0.1 \mathrm{ml}$ immediately after being dissolved. Statistical comparisons were made using the paired $t$-test, and effects were considered to be significant at the $P<0.05$ level. Statistically significant diabetogenic effects are routinely obtained in this assay with $10-25 \mu \mathrm{g}$ of highly purified native $22-\mathrm{kDa}$ GH [25-27].

\section{Assay of insulin-like activity}

The $20-\mathrm{kDa}$ GH was tested for in vitro insulinlike activity by assessing its ability to stimulate $\left[{ }^{14} \mathrm{C}\right]$ glucose oxidation to ${ }^{14} \mathrm{CO}_{2}$ by isolated epididymal adipose tissue from hypophysectomized rats, as previously described in detail [28]. The activity of the $20-\mathrm{kDa} \mathrm{GH}$ was compared to that of purified native human GH monomer (1.1 $\mathrm{IU} / \mathrm{mg}$ ) isolated and purified by ion-exchange chromatography as previously described [29]. Statistical comparisons were made with Dunnet's test, and a difference was considered significant if $P<$ 0.05 .

\section{Results}

The ability of the purified native $20-\mathrm{kDa}$ GH to stimulate body weight gain in hypophysectomized rats compared to that of $22-\mathrm{kDa} \mathrm{GH}$ is shown in Table I. It can be seen that, like $22-\mathrm{kDa} \mathrm{GH}$,
20-kDa GH stimulated body weight gain in a dose-dependent manner during the course of treatment in both experiments 1 and 2 . In both experiments, however, $20-\mathrm{kDa}$ GH generally produced smaller mean net changes in body weight than did 22-kDa GH at both the 6 and $60 \mu \mathrm{g}$ daily doses used. When the data were analysed using a parallel line bioassay program, the potency of the $20-\mathrm{kDa} \mathrm{GH}$ relative to that of the $22-\mathrm{kDa} \mathrm{GH}$ in experiment 1 was $0.54(0.35-0.80,95 \%$ confidence limits) and in experiment 2 was $0.60(0.44-0.81)$.

The effects of $20-\mathrm{kDa} \mathrm{GH}$ on longitudinal bone growth and tibial epiphyseal width are compared with those of $22-\mathrm{kDa}$ GH in Table II. The $20-\mathrm{kDa}$ $\mathrm{GH}$ behaved like $22-\mathrm{kDa} \mathrm{GH}$ in stimulating longitudinal bone growth and increasing tibial epiphyseal width in a dose-dependent fashion. Again, in both experiments, $20-\mathrm{kDa} \mathrm{GH}$ appeared to be somewhat less effective than $22-\mathrm{kDa} \mathrm{GH}$ in stimulating both longitudinal bone growth and tibial epiphyseal width. When the data for longitudinal bone growth were analysed using the parallel line bioassay program, the potency of the $20-\mathrm{kDa}$ $\mathrm{GH}$ relative to that of the $22-\mathrm{kDa} \mathrm{GH}$ in experiment 1 was $0.50(0.23-0.92)$ and in experiment 2 was $0.62(0.35-1.04)$. Thus, the estimated potency of $20-\mathrm{kDa} \mathrm{GH}$ in this assay was quite similar to that found in the body weight gain studies described above.

Table III summarizes the results obtained with $20-\mathrm{kDa} \mathrm{GH}$ and $22-\mathrm{kDa} \mathrm{GH}$ on $\left[{ }^{35} \mathrm{~S}\right]$ sulfate incorporation into various cartilages of the hypophysectomized rat. In the case of all four cartilages examined (costal, xiphoid, proximal tibia and proximal femur), both hormones stimulated $\left[{ }^{35}\right.$ S]sulfate incorporation in a dose-dependent manner, and, again, the $20-\mathrm{kDa} \mathrm{GH}$ appeared to be somewhat less effective in stimulating sulfation than was 22-kDa GH.

Various organs, including the liver, lungs, kidneys, heart and testes, were removed from the $20-\mathrm{kDa}$ GH- and 22-kDa GH-treated rats on the final day of the experiment, and their wet weights were compared. Both hormones increased the wet weight of all of these organs over those of the vehicle-treated controls (data not shown).

Last, Table IV summarizes the effects of the course of treatment with $20-\mathrm{kDa} \mathrm{GH}$ and $22-\mathrm{kDa}$ $\mathrm{GH}$ on the concentration of IGF-1 in the serum of 
TABLE I

EFFECTS OF NATIVE 22-kDa GH AND NATIVE 20-kDa GH ON BODY WEIGHT GAIN BY HYPOPHYSECTOMIZED RATS

Treatment with $22-\mathrm{kDa}$ or $20-\mathrm{kDa}$ GH was begun on day 6 of the experiment, and the last hormone injection was given on day 15 . The values given are the net changes in body weight in $\mathrm{g}$ from body weights measured on day 6 . Values represent the mean \pm S.E. of $n$ observations.

\begin{tabular}{|c|c|c|c|c|c|}
\hline \multirow[t]{2}{*}{ Treatment } & \multirow[t]{2}{*}{$n$} & \multicolumn{4}{|c|}{ Net change in body weight $(\mathrm{g})$} \\
\hline & & day 8 & day 10 & day 13 & day 16 \\
\hline \multicolumn{6}{|l|}{ Experiment 1} \\
\hline Vehicle & 7 & $2.4 \pm 0.3$ & $5.3 \pm 0.6$ & $8.4 \pm 0.8$ & $9.4 \pm 0.8$ \\
\hline \multicolumn{6}{|l|}{ 22-kDa GH } \\
\hline $6 \mu \mathrm{g} / \mathrm{day}$ & 6 & $5.7 \pm 0.7$ & $13.3 \pm 1.2$ & $20.0 \pm 1.0$ & $25.0 \pm 1.5$ \\
\hline $60 \mu \mathrm{g} /$ day & 7 & $10.6 \pm 0.5$ & $22.9 \pm 0.7$ & $36.6 \pm 1.2$ & $48.1 \pm 2.3$ \\
\hline \multicolumn{6}{|l|}{$20-\mathrm{kDa} G H$} \\
\hline $6 \mu \mathrm{g} /$ day & 7 & $6.0 \pm 0.6$ & $12.1 \pm 0.6$ & $19.3 \pm 0.6$ & $21.6 \pm 1.0$ \\
\hline $60 \mu \mathrm{g} /$ day & 7 & $8.9 \pm 0.8$ & $20.0 \pm 1.3$ & $32.0 \pm 1.7$ & $41.1 \pm 1.9$ \\
\hline \multicolumn{6}{|l|}{ Experiment 2} \\
\hline Vehicle & 6 & $3.2 \pm 0.6$ & $7.5 \pm 0.6$ & $10.7 \pm 0.6$ & $12.7 \pm 0.8$ \\
\hline \multicolumn{6}{|l|}{ 22-kDa GH } \\
\hline $6 \mu \mathrm{g} /$ day & 5 & $7.4 \pm 1.2$ & $17.0 \pm 0.5$ & $24.6 \pm 1.0$ & $27.0 \pm 1.1$ \\
\hline $60 \mu \mathrm{g} /$ day & 6 & $11.2 \pm 0.8$ & $23.8 \pm 1.1$ & $37.8 \pm 1.5$ & $48.7 \pm 1.6$ \\
\hline \multicolumn{6}{|l|}{$20 \mathrm{kDa} \mathrm{GH}$} \\
\hline $6 \mu \mathrm{g} / \mathrm{day}$ & 6 & $5.3 \pm 0.2$ & $13.3 \pm 0.4$ & $19.5 \pm 0.6$ & $22.8 \pm 0.6$ \\
\hline $60 \mu \mathrm{g} /$ day & 6 & $10.7 \pm 0.4$ & $23.8 \pm 0.6$ & $35.3 \pm 0.6$ & $43.5 \pm 1.6$ \\
\hline
\end{tabular}

TABLE II

EFFECTS OF NATIVE 22-kDa GH AND NATIVE 20-kDa GH ON LONGITUDINAL TIBIA GROWTH AND TIBIA EPIPHYSEAL WIDTH OF HYPOPHYSECTOMIZED RATS

Values represent the mean $\pm S$.E. of $n$ observations.

\begin{tabular}{|c|c|c|c|}
\hline Treatment & $n$ & $\begin{array}{l}\text { Longitudinal } \\
\text { growth } \\
(\mu \mathrm{m})\end{array}$ & $\begin{array}{l}\text { Epiphyseal } \\
\text { width } \\
(\mu \mathrm{m})\end{array}$ \\
\hline \multicolumn{4}{|l|}{ Experiment 1} \\
\hline $\begin{array}{l}\text { Vehicle } \\
\text { 22-kDa GH }\end{array}$ & 3 & $816 \pm 101$ & $215 \pm 4$ \\
\hline $6 \mu \mathrm{g} / \mathrm{day}$ & 3 & $1417 \pm 101$ & $308 \pm 7$ \\
\hline $60 \mu \mathrm{g} / \mathrm{day}$ & 6 & $1851 \pm 38$ & $373 \pm 7$ \\
\hline \multicolumn{4}{|l|}{$20-\mathrm{kDa} \mathrm{GH}$} \\
\hline $6 \mu \mathrm{g} /$ day & 5 & $1285 \pm 63$ & $291 \pm 7$ \\
\hline $60 \mu \mathrm{g} /$ day & 4 & $1738 \pm 26$ & $360 \pm 10$ \\
\hline \multicolumn{4}{|l|}{ Experiment 2} \\
\hline Vehicle & 6 & $599 \pm 26$ & $181 \pm 7$ \\
\hline \multicolumn{4}{|l|}{$22 \cdot \mathrm{kDa}$} \\
\hline $6 \mu \mathrm{g} /$ day & 5 & $1133 \pm 51$ & $231 \pm 4$ \\
\hline $60 \mu \mathrm{g} /$ day & 3 & $1512 \pm 18$ & $282 \pm 5$ \\
\hline \multicolumn{4}{|l|}{ 20-kDa GH } \\
\hline $6 \mu \mathrm{g} / \mathrm{day}$ & 5 & $1034 \pm 41$ & $210 \pm 10$ \\
\hline $60 \mu \mathrm{g} / \mathrm{day}$ & 4 & $1437 \pm 21$ & $248 \pm 8$ \\
\hline
\end{tabular}

the hypophysectomized rats, as measured by a radioreceptor assay that detects both free and protein-bound IGF-1. On day 1 of both experiments, all animals within a given experiment had IGF-1 levels that were roughly equivalent, although the starting values in experiment 2 were approximately twice those in experiment 1 . By day 6 , the IGF-1 levels of all groups had approximately doubled, most probably due to the thyroxine administered on days 4 and 5 [22]. The course of treatment with $6 \mu \mathrm{g} /$ day of either $20-\mathrm{kDa}$ or 22-kDa GH had little further effect on IGF-1 levels, and, in any event, the mean values on day 16 were equivalent for $20-\mathrm{kDa} \mathrm{GH}-$ and $22-\mathrm{kDa}$ GH-treated animals. At a dose of $60 \mu \mathrm{g} /$ day, both $20-\mathrm{kDa}$ and $22-\mathrm{kDa} \mathrm{GH}$ produced significant increases in IGF-1 level over that existing on Day 6 of the studies. However, in both experiments, the percent increase in IGF-1 level over the mean value on Day 6 was greater in $22-\mathrm{kDa}$ GH-treated rats than in the $20-\mathrm{kDa}$ GH-treated animals (see Table IV), suggesting again that the $20-\mathrm{kDa}$ GH was somewhat less potent than $22-\mathrm{kDa}$ 
TABLE III

EFFECTS OF NATIVE 22-kDa GH AND NATIVE 20-kDa GH ON $\left[{ }^{35}\right.$ S $]$ SULFATE INCORPORATION INTO VARIOUS CARTILAGES OF HYPOPHYSECTOMIZED RATS

Values represent the mean \pm S.E. of $n$ observations.

\begin{tabular}{|c|c|c|c|c|c|}
\hline \multirow[t]{2}{*}{ Treatment } & \multirow[t]{2}{*}{$n$} & \multicolumn{4}{|c|}{$\left[{ }^{35} \mathrm{~S}\right]$ Sulfate incorporation (dpm/mg dry weight) } \\
\hline & & costal & xiphoid & proximal tibia & proximal femur \\
\hline \multicolumn{6}{|l|}{ Experiment 1} \\
\hline Vehicle & 7 & $311 \pm 23$ & $889 \pm 101$ & $346 \pm 29$ & $315 \pm 22$ \\
\hline \multicolumn{6}{|l|}{ 22-kDa GH } \\
\hline $6 \mu \mathrm{g} /$ day & 6 & $642 \pm 55$ & $1514 \pm 156$ & $619 \pm 75$ & $618 \pm 54$ \\
\hline $60 \mu \mathrm{g} / \mathrm{day}$ & 7 & $1256 \pm 124$ & $2579 \pm 356$ & $934 \pm 98$ & $1012 \pm 67$ \\
\hline \multicolumn{6}{|l|}{$20-\mathrm{kDa}$ GH } \\
\hline $6 \mu \mathrm{g} /$ day & 7 & $497 \pm 48$ & $1204 \pm 211$ & $438 \pm 25$ & $501 \pm 32$ \\
\hline $60 \mu \mathrm{g} /$ day & 7 & $1024 \pm 121$ & $2029 \pm 235$ & $719 \pm 53$ & $826 \pm 62$ \\
\hline \multicolumn{6}{|l|}{ Experiment 2} \\
\hline Vehicle & 6 & $139 \pm 9$ & $209 \pm 25$ & $154 \pm 27$ & $120 \pm 10$ \\
\hline \multicolumn{6}{|l|}{ 22-kDa GH } \\
\hline $6 \mu \mathrm{g} /$ day & 5 & $291 \pm 12$ & $520 \pm 43$ & $223 \pm 42$ & $201 \pm 12$ \\
\hline $60 \mu \mathrm{g} /$ day & 6 & $545 \pm 34$ & $817 \pm 84$ & $376 \pm 21$ & $301 \pm 13$ \\
\hline \multicolumn{6}{|l|}{ 20-kDa GH } \\
\hline $6 \mu \mathrm{g} / \mathrm{day}$ & 6 & $256 \pm 16$ & $435 \pm 47$ & $260 \pm 24$ & $179 \pm 10$ \\
\hline $60 \mu \mathrm{g} /$ day & 6 & $369 \pm 36$ & $554 \pm 49$ & $269 \pm 23$ & $233 \pm 21$ \\
\hline
\end{tabular}

TABLE IV

EFFECTS OF NATIVE 22-kDa GH AND NATIVE 20-kDa GH ON IGF-1 LEVELS IN SERUM FROM HYPOPHYSECTOMIZED RATS

Values represent the mean \pm S.E. of $n$ observations.

\begin{tabular}{|c|c|c|c|c|}
\hline \multirow[t]{2}{*}{ Treatment } & \multirow[t]{2}{*}{$n$} & \multicolumn{3}{|c|}{$\begin{array}{l}\text { IGF level by radioreceptor assay } \\
(\mathrm{U} / \mathrm{ml})\end{array}$} \\
\hline & & day 1 & day 6 & day 16 \\
\hline \multicolumn{5}{|l|}{ Experiment 1} \\
\hline Vehicle & 7 & $0.94 \pm 0.16$ & $2.09 \pm 0.31$ & $1.36 \pm 0.15$ \\
\hline \multicolumn{5}{|l|}{ 22-kDa GH } \\
\hline $6 \mu \mathrm{g} / \mathrm{day}$ & 6 & $1.28 \pm 0.27$ & $2.03 \pm 0.37$ & $2.18 \pm 0.38$ \\
\hline $60 \mu \mathrm{g} /$ day & 7 & $1.03 \pm 0.08$ & $2.28 \pm 0.26$ & $7.63 \pm 1.12$ \\
\hline \multicolumn{5}{|l|}{ 20-kDa GH } \\
\hline $6 \mu \mathrm{g} /$ day & 7 & $1.32 \pm 0.09$ & $2.44 \pm 0.31$ & $1.96 \pm 0.35$ \\
\hline $60 \mu \mathrm{g} /$ day & 7 & $0.99 \pm 0.14$ & $2.31 \pm 0.29$ & $4.13 \pm 0.33$ \\
\hline \multicolumn{5}{|l|}{ Experiment 2} \\
\hline Vehicle & 6 & $2.54 \pm 0.22$ & $4.41 \pm 0.57$ & $3.05 \pm 0.20$ \\
\hline \multicolumn{5}{|l|}{ 22-kDa GH } \\
\hline $6 \mu \mathrm{g} / \mathrm{day}$ & 5 & $2.40 \pm 0.41$ & $4.62 \pm 0.78$ & $3.92 \pm 0.29$ \\
\hline $60 \mu \mathrm{g} /$ day & 6 & $1.78 \pm 0.37$ & $4.80 \pm 0.61$ & $8.70 \pm 0.72$ \\
\hline \multicolumn{5}{|l|}{ 20-kDa GH } \\
\hline $6 \mu \mathrm{g} / \mathrm{day}$ & 6 & $2.40 \pm 0.31$ & $6.56 \pm 0.35$ & $3.64 \pm 0.29$ \\
\hline $60 \mu \mathrm{g} / \mathrm{day}$ & 6 & $2.44 \pm 0.29$ & $6.10 \pm 0.51$ & $8.45 \pm 0.85$ \\
\hline
\end{tabular}

$\mathrm{GH}$ in this assay for growth-promoting activity.

The native $20-\mathrm{kDa} \mathrm{GH}$ was tested for diabetogenic activity by examining its ability to raise fasting blood glucose concentration and decrease glucose tolerance when injected chronically into $o b / o b$ mice. Fig. 4 illustrates the results obtained when $20-\mathrm{kDa} \mathrm{GH}$ was tested for diabetogenic activity at doses of $5,10,25$ or $50 \mu \mathrm{g} /$ day for 3 days. When $20-\mathrm{kDa} \mathrm{GH}$ was administered at a dose of $5 \mu \mathrm{g} /$ day, it had no effect on either fasting blood glucose concentration or glucose tolerance (see Fig. 4A). When the dose was increased to $10 \mu \mathrm{g} / \mathrm{day}$, there was again no effect on fasting blood glucose concentration, but a modest decrease in glucose tolerance was observed (Fig. 4A). When the dose of $20-\mathrm{kDa} \mathrm{GH}$ was raised to $25 \mu \mathrm{g} /$ day, both an increase in fasting blood glucose and a decrease in glucose tolerance were obtained (Fig. 4B). Large changes in both fasting blood glucose concentration and glucose tolerance were obtained when $20-\mathrm{kDa} \mathrm{GH}$ was administered at a dose of $50 \mu \mathrm{g} /$ day (Fig. 4B) This dose response relationship is similar to that routinely obtained in our laboratory with purified native $22-\mathrm{kDa}$ GH [25-27]. 

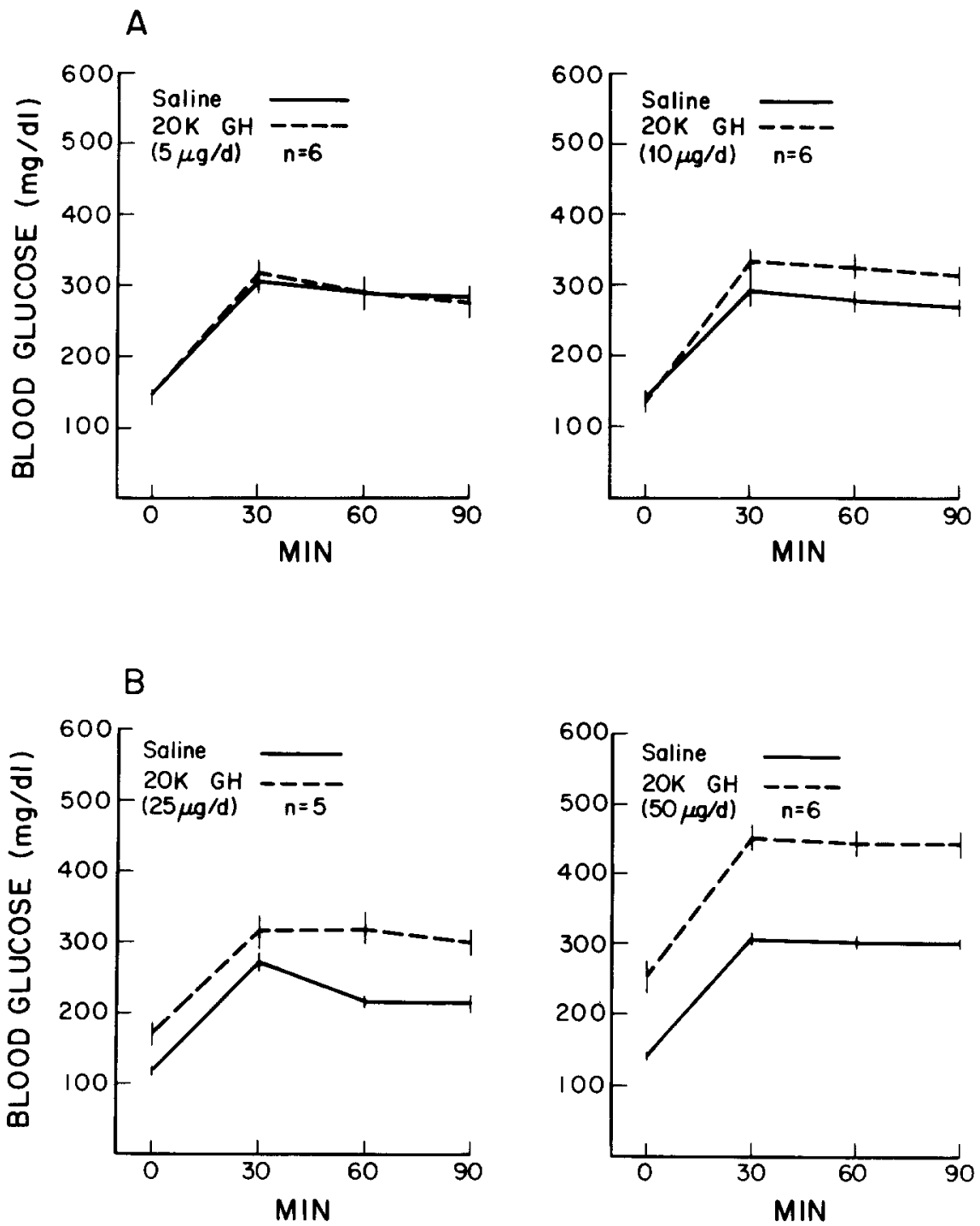

Fig. 4. Effects of treatment with 5 or $10 \mu \mathrm{g} /$ day of $20-\mathrm{kDa}$ GH (A) and 25 or $50 \mu \mathrm{g} /$ day of $20-\mathrm{kDa}$ GH (B) on glucose tolerance in fasted $o b / o b$ mice. Each point represents the mean of $n$ observations. Vertical lines through the points indicate 2 S. Es. The effects of the $10 \mu \mathrm{g} /$ day dose of $20-\mathrm{kDa}$ GH were significant $(P<0.05)$ at the 60 and 90 min time points. The effects of the $25 \mathrm{and} 50 \mu \mathrm{g} / \mathrm{day}$ doses of $20-\mathrm{kDa}$ GH were statistically significant at all time points examined.

The in vitro insulin-like activity of the purified native $20-\mathrm{kDa}$ GH preparation is compared with that of native $22-\mathrm{kDa} \mathrm{GH}$ in Table V. Purified $22-\mathrm{kDa} \mathrm{GH}$ produced statistically significant increases in $\left[{ }^{14} \mathrm{C}\right]$ glucose oxidation to ${ }^{14} \mathrm{CO}_{2}$ by isolated rat epididymal adipose tissue when employed at concentrations of 2 or $10 \mathrm{nM}$. On the other hand, 5 times the concentration of $20-\mathrm{kDa}$ $\mathrm{GH}(10$ or $50 \mathrm{nM})$ was required to produce responses comparable to those obtained with 2 or 10 $\mathrm{nM} 22-\mathrm{kDa} \mathrm{GH}$. Thus, native $20-\mathrm{kDa} \mathrm{GH}$ has intrinsic in vitro insulin-like activity, but this activity is considerably less than that of native 22$\mathrm{kDa} \mathrm{GH}$. 
TABLE V

IN VITRO EFFECTS OF NATIVE 22-kDa GH AND NATIVE 20-kDa GH ON $\left[{ }^{14} \mathrm{C}\right]$ GLUCOSE OXIDATION BY EPIDIDYMAL ADIPOSE TISSUE OF HYPOPHYSECTOMIZED RATS

Values represent the mean \pm S.E. of $n$ observations. * Significantly different from the control $(P<0.05)$

\begin{tabular}{lcrl}
\hline Material & $\begin{array}{l}\text { Conc. } \\
(\mathrm{nM})\end{array}$ & \multicolumn{1}{c}{$n$} & $\begin{array}{l}{ }^{14} \mathrm{CO}_{2} \text { production } \\
(\mathrm{dpm} / \mathrm{mg} \text { tissue per } \mathrm{h})\end{array}$ \\
\hline Control & & 22 & $36.6 \pm 2.6$ \\
22-kDa GH & 0.4 & 7 & $32.0 \pm 2.2$ \\
& 2 & 21 & $54.3 \pm 3.6^{*}$ \\
& 10 & 15 & $86.2 \pm 9.6^{*}$ \\
$20-\mathrm{kDa}$ GH & 2 & 6 & $33.1 \pm 3.0^{*}$ \\
& 10 & 20 & $50.8 \pm 4.2^{*}$ \\
& 50 & 14 & $75.4 \pm 5.2^{*}$ \\
\hline
\end{tabular}

\section{Discussion}

In the past, it has been difficult to isolate native 20-kDa GH in monomeric form, free of significant contamination with $22-\mathrm{kDa}$ GH. As a consequence, attempts to determine whether $20-\mathrm{kDa}$ $\mathrm{GH}$ has a biological activity profile distinct from that of $22-\mathrm{kDa} \mathrm{GH}$ have been compromised. In the present study, a method was devised for the purification of monomeric $20-\mathrm{kDa}$ GH from human pituitary glands, which utilized column electrophoresis in agarose gel as a final purification step. This procedure yielded a highly purified monomeric preparation of $20-\mathrm{kDa} \mathrm{GH}$, which was contaminated to an extent of less than $1 \%$ with $22-\mathrm{kDa} \mathrm{GH}$. Moreover, this preparation of $20-\mathrm{kDa}$ $\mathrm{GH}$ appeared to be reasonably stable, since it exhibited only a small degree of dimerization upon storage for several months. Thus, the availability of this preparation of native $20-\mathrm{kDa} \mathrm{GH}$ afforded an opportunity to determine whether the biological properties of $20-\mathrm{kDa} \mathrm{GH}$ differ in any significant respect from those of $22-\mathrm{kDa} \mathrm{GH}$.

In agreement with previous reports $[2,7]$, the native $20-\mathrm{kDa} \mathrm{GH}$ preparation was found to possess considerable activity in stimulating growth in the hypophysectomized rat, when growth was assessed in a variety of ways. However, it was somewhat less active than the native $22-\mathrm{kDa} G H$ preparation to which it was compared in all of the tests for growth that were used. When the data obtained in the body weight gain and longitudinal bone growth assays were submitted to analysis using a parallel line bioassay program, the estimated potency of the $20-\mathrm{kDa} \mathrm{GH}$ was 0.6 that of the $22-\mathrm{kDa} \mathrm{GH}$ preparation. Considering that the 22-kDa GH used has an estimated growth potency of $3 \mathrm{IU} / \mathrm{mg}$, the $20-\mathrm{kDa} \mathrm{GH}$ would then have a potency of approximately $1.8 \mathrm{IU} / \mathrm{mg}$. This is within the range of potencies $(0.9-1.8 \mathrm{IU} / \mathrm{mg})$ recorded for various native $20-\mathrm{kDa} \mathrm{GH}$ preparations in the weight gain assay by Lewis et al. [2]. Whether the substantial growth-promoting activity observed here and in previous studies is, indeed, due to high intrinsic activity of the $20-\mathrm{kDa} \mathrm{GH}$ molecule has been questioned recently by Baumann et al. [30]. Since 20-kDa GH has been found to interact poorly in some but not all receptor assays for $\mathrm{GH}$, compared to $22-\mathrm{kDa} \mathrm{GH}$ (for review, see Ref. 31), these investigators proposed that the high growth-promoting activity of $20-\mathrm{kDa}$ $\mathrm{GH}$ results from its slow clearance from the circulation. Indeed, Baumann et al. [30] demonstrated that the metabolic clearance rate of $20-\mathrm{kDa} \mathrm{GH}$ in the rat is significantly slower than that of $22-\mathrm{kDa}$ $\mathrm{GH}$. However, it is possible that the low degree of binding of $20-\mathrm{kDa} \mathrm{GH}$ observed in certain receptor assays and the apparent slow rate of metabolic clearance of the variant are, in fact, due to its great propensity to aggregate, as discussed earlier. Thus, these findings may or may not have bearing on the question of the degree of intrinsic growthpromoting activity possessed by $20-\mathrm{kDa} \mathrm{GH}$.

The native $20-\mathrm{kDa} \mathrm{GH}$ preparation exhibited substantial diabetogenic activity when tested for the ability to raise fasting blood glucose concentration and impair glucose tolerance in $o b / o b$ mice. These results are in accord with recent observations [9] demonstrating that biosynthetic human 20-kDa methionyl-GH is diabetogenic, thus establishing with certainty that diabetogenic activity is an intrinsic property of the $20-\mathrm{kDa}$ variant of human GH. Moreover, the native $20-\mathrm{kDa} \mathrm{GH}$ preparation exhibited significant in vitro insulinlike activity, although its potency was considerably lower than that of native $22-\mathrm{kDa}$ GH. This observation again agrees with recent findings [9] employing biosynthetic human 20-kDa methionyl$\mathrm{GH}$, which indicated that the latter possessed $20 \%$ 
of the in vitro insulin-like activity of biosynthetic human 22-kDa methionyl-GH. Thus, insulin-like activity is also an intrinsic property of $20-\mathrm{kDa}$ $\mathrm{GH}$. Its attenuated insulin-like activity may reflect either that the deleted sequence (residues 32-46) is part of the active site for this activity of $\mathrm{GH}$ or that the altered conformation of $20-\mathrm{kDa}$ GH may interfere with the expression of its insulin-like activity, as has recently been proposed [9].

\section{Acknowledgements}

Financial support from the Swedish Medical Research Council (Project No. 5921) is gratefully acknowledged. C.M.C. was a recipient of a $\mathrm{Na}$ tional Research Service Award (AM-07268). N.A.A. was the recipient of a fellowship from the American Diabetes Association, Michigan Affiliate.

\section{References}

1 Singh, R.N.P., Seavey, B.K. and Lewis, U.J. (1974) Endocrinol. Res. Commun. 1, 449-464

2 Lewis, U.J., Dunn, J.T., Bonewald, L.F., Seavey, B.K. and VanderLaan, W.P. (1978) J. Biol. Chem. 253, 2679-2687

3 Lewis, U.J., Bonewald, L.F. and Lewis, L.J. (1980) Biochem. Biophys. Res. Commun. 92, 511-516

4 Singh, R.N.P. and Lewis, U.J. (1981) Prep. Biochem. 11, $559-570$

5 Chapman, G.E., Rogers, K.M., Brittain, T., Bradshaw, R.A., Bates, O.J., Turner, C., Cary, P.D. and Crane-Robinson, C. (1981) J. Biol. Chem. 256, 2395-2401

6 DeNoto, F.M., Moore, D.D. and Goodman, H.M. (1981) Nucleic Acids Res. 9, 3719-3730

7 Lewis, U.J., Singh, R.N.P. and Tutwiler, G.F. (1981) Endocrinol. Res. Commun. 8, 155-164

8 Frigeri, L.G., Peterson, S.M. and Lewis, U.J. (1979) Biochem. Biophys. Res. Commun. 91, 778-782

9 Kostyo, J.L., Cameron, C.M., Olson, K.C., Jones, A.J.S. and Pai, R.C. (1985) Proc. Natl. Acad. Sci. USA 82, $4250-4253$
10 Tinsley, F.C., Grinna, E.L., Baker, S.H., Powell, J.G., Bemis, K.G. and Shaar, C.J. (1986) Biochem. Biophys. Res. Commun. 138, 342-348

11 Roos, P., Fevold, H.R. and Gemzell, C.A. (1963) Biochim. Biophys. Acta 74, 525-531

12 Roos, P., Jacobsson, G. and Wide, L. (1975) Biochim. Biophys. Acta 379, 247-261

13 Hjertén, S. (1963) J. Chromatogr. 12, 510-526

14 Hjertén, S., Hoglund, S. and Ruttkay-Nedecky, G. (1970) Acta Virol. 14, 89-101

15 Neville, D.M. (1971) J. Biol. Chem. 246, 6328-6334

16 Hjertén, S. (1962) Arch. Biochem. Biophys., Suppl. 1, 147-151

17 Vesterberg, O. and Gramstrup-Christensen, B. (1984) Electrophoresis 5, 282-285

18 Hansson, L.F., Menander-Sellman, K., Stenstrom, A. and Thorngren, K.-G. (1972) Calcif. Tissue Res. 10, 238-251

19 Thorngren, K.-G., Hansson, L.I. and Sundin, G. (1980) J. Endocrinol. 84, 199-204

20 Thorngren, K.-G. and Hansson, L.I. (1974) Acta Endocrinol. 76, 35-52

21 Hall, R., Takano, K. and Fryklund, L. (1974) J. Clin. Endocrinol. Metab 39, 973-976

22 Skottner, A., Forsman, A., Lofberg, E. and Thorngren, K.-G. (1984) Acta Endocrinol. 107, 192-198

23 Armitage, P. (1977) Statistical Methods in Medical Research, Ch. 17, Wiley, New York

24 Reagan, C.R. (1978) Diabetes 27, 883-888

25 Kostyo, J.L., Gennick, S.E. and Sauder, S.E. (1984) Am. J. Physiol. 246, E356-E360

26 Cameron, C.M., Kostyo, J.L. and Papkoff, H. (1985) Endocrinology 116, 1501-1505

27 Cameron, C.M., Kostyo, J.L., Kumar, V. and Gennick, S.E. (1985) Biochim. Biophys. Acta 841, 254-260

28 Mills, J.B., Kostyo, J.L., Reagan, C.R., Wagner, S.A., Moseley, M.H. and Wilhelmi, A.E. (1980) Endocrinology 107, 391-399

29 Mills, J.B., Ashworth, R.B., Wilhelmi, A.E. and Hartree, A.S. (1969) J. Clin. Endocrinol. Metab. 29, 1456-1459

30 Baumann, G., Stolar, M.W. and Buchanan, T.A. (1985) Endocrinology 117, 1309-1313

31 Smal, J., Closset, J., Hennen, G. and DeMeyts, P. (1986) Biochem. Biophys. Res. Commun. 134, 159-165 